\title{
In Memoriam - Zena Werb 1945-2020
}

\author{
Mary Helen Barcellos-Hoff ${ }^{1} \cdot$ Valerie M. Weaver $^{1}$
}

Received: 11 September 2020 / Accepted: 17 September 2020 / Published online: 30 September 2020

(C) Springer Science+Business Media, LLC, part of Springer Nature 2020

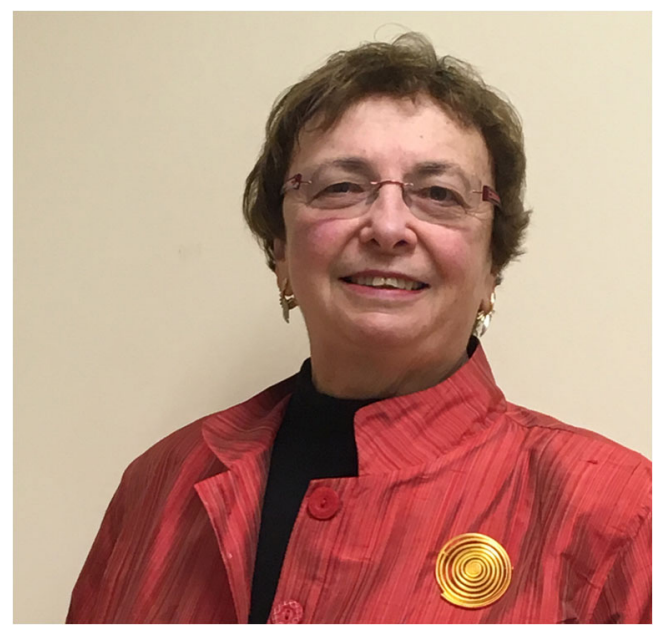

Zena Werb died suddenly on 16 June 2020 at the age of 75 . She devoted much of her scientific life to interrogating and explaining the biology of the mammary gland. From the importance of macrophages during involution to the remodeling of the extracellular matrix during mammary gland development and the pathogenesis of breast cancer, she pioneered the integration of cell biology with molecular pathology of cancer. Her studies on tumor-associated inflammation were among the first to describe how cancer results from co-evolution. Her reputation as a rigorous and prolific scientist made her one of the most respected researchers in the world as recognized by election to the National Academy of Sciences, as fellow of the American Association for Cancer Research, her presidency of the American Society of Cell Biology, her receipt of the E.B. Wilson Medal from the American Society of Cell Biology and the Paget-Ewing Award from the Metastasis Research Society, among many other awards and honors.

Mary Helen Barcellos-Hoff

Mary.Barcellos-Hoff@ucsf.edu

1 University of California, San Francisco, CA, USA
Zena was born into hardship, but went on to determine her own unique path as an academic and scientist. She was born in the Bergen-Belsen Nazi concentration camp in Germany. Her family eventually emigrated to rural Canada, where she attended a one-room school. Primed by an appreciation of the hard work to get through long winters, she attend the University of Toronto before her graduate studies and research in lipid metabolism in macrophages with Zanvil A. Cohn at Rockefeller University, and postdoctoral training with John T. Dingle at the Strangeways Research Laboratory, in Cambridge, England. She began a lab at the University of California, San Francisco (UCSF) in 1976, where her early independent research focused on identifying and characterizing matrix metalloproteinases produced by fibroblasts and macrophages.

Zena established expertise in research ranging from embryogenesis to development to pathology. In analyzing not only what cells contributed to the microenvironment, but how they remodeled their environment, she began charting the biology of tissues and laying the groundwork for understanding complex processes. In the late 80 's she began a productive collaboration with Mina J. Bissell leading to the first description of proteinases in the mammary gland. Zena published nearly 200 papers in mammary gland biology and breast cancer that now form the basis for understanding how the gland remodels during involution and is remodeled during neoplastic progression. She drew the parallel between mammary gland branching morphogenesis and invasive cancer using state of the art imaging and organotypic cultures.

Zena was known for not only shining a light on, but also providing insight into, the hard problems of cancer biology. Her research highlighted the importance of biological crosstalk during processes that lead to cancer and metastasis. In an interview in January of the year she died, she predicted that by 2050 , cancer would be a disease that people die with, rather than of, by using the knowledge of microenvironment's role to keep cancer cells 'under wraps'. With more than 100,000 citations to her work, it is difficult to say which of her contributions is most significant, but one might note that her seminal review of cancer and inflammation, co-authored by mentee, Lisa Coussens, has been cited more than 10,000 times in less than 20 years. 
At the time of her death, she was Professor in the Department of Anatomy at UCSF, in which she had recently stepped down from Vice Chair, and was the Associate Director for Basic Science at the UCSF Helen Diller Family Comprehensive Cancer Center. During her nearly 40 years at UCSF, she was known as a devoted mentor and advocate, which was recognized by the UCSF Lifetime Achievement in Mentoring Award in 2015. Her mentees, many of whom have gone on to expand and extend our understanding of mammary biology and breast cancer, laud her unique combination of rigor and warmth that provided a foundation for their careers.

Zena's work speaks for itself; her science is spoken of by many, a legacy we will all reap.

Publisher's Note Springer Nature remains neutral with regard to jurisdictional claims in published maps and institutional affiliations. 